\title{
Synthesis of $O^{6}$-alkylated $\mathrm{preQ}_{1}$ derivatives
}

\author{
Laurin Flemmich, Sarah Moreno and Ronald Micura ${ }^{*}$
}

\author{
Full Research Paper \\ Address: \\ Institute of Organic Chemistry, Center for molecular Biosciences \\ Innsbruck (CMBI), Innrain 80-82, 6020 Innsbruck, Austria \\ Email: \\ Ronald Micura* - ronald.micura@uibk.ac.at \\ * Corresponding author \\ Keywords: \\ deazapurines; heterocycles; pyrrolopyrimidines; queuosine; RNA \\ cofactors; RNA methylation
}

\author{
Beilstein J. Org. Chem. 2021, 17, 2295-2301. \\ https://doi.org/10.3762/bjoc.17.147 \\ Received: 12 June 2021 \\ Accepted: 27 August 2021 \\ Published: 02 September 2021 \\ Associate Editor: K. N. Allen \\ (C) 2021 Flemmich et al.; licensee Beilstein-Institut. \\ License and terms: see end of document.
}

\begin{abstract}
A naturally occurring riboswitch can utilize 7-aminomethyl- $O^{6}$-methyl-7-deazaguanine $\left(\mathrm{m}^{6} \mathrm{preQ}_{1}\right)$ as cofactor for methyl group transfer resulting in cytosine methylation. This recently discovered riboswitch-ribozyme activity opens new avenues for the development of RNA labeling tools based on tailored $O^{6}$-alkylated preQ ${ }_{1}$ derivatives. Here, we report a robust synthesis for this class of pyrrolo[2,3- $d$ ] pyrimidines starting from readily accessible $N^{2}$-pivaloyl-protected 6-chloro-7-cyano-7-deazaguanine. Substitution of the 6-chloro atom with the alcoholate of interest proceeds straightforward. The transformation of the 7-cyano substituent into the required aminomethyl group turned out to be challenging and was solved by a hydration reaction sequence on a well-soluble dimethoxytritylated precursor via in situ oxime formation. The synthetic path now provides a solid foundation to access $O^{6}$-alkylated 7-aminomethyl-7-deazaguanines for the development of RNA labeling tools based on the preQ ${ }_{1}$ class-I riboswitch scaffold.
\end{abstract}

\section{Introduction}

Methylated preQ $_{1}$ has attracted much attention recently because this compound has been found to function as cofactor for the conserved fold of a non-coding RNA, namely the preQ $_{1}$ class-I riboswitch [1]. This riboswitch acts as a ribozyme by using 7-aminomethyl- $O^{6}$-methyl-7-deazaguanine $\left(\mathrm{m}^{6} \mathrm{preQ}_{1}\right)$ as methyl group donor; it catalyzes self-methylation of a specific cytidine in the aptamer binding pocket, yielding N3-methyl cytidine $\left(\mathrm{m}^{3} \mathrm{C}\right)$ under release of 7-aminomethyl-7-deazaguanine $\left(\mathrm{preQ}_{1}\right)$ [1]. Thus far, present-day riboswitches have only been known to bind - but not to be able to react - with their ligands $[2,3]$. This new finding now opens exciting avenues for the development of RNA labeling tools [4], in particular, for
RNA methylation, and more generally, for RNA alkylation. To this end, robust synthetic routes towards $O^{6}$-alkylated 7-aminomethyl-7-deazaguanines are urgently needed and reported here.

\section{Results and Discussion}

Biological and synthetic background

Role of pre $\mathrm{Q}_{1}$ in queuosine biosynthesis and gene regulation

Queuine ( $Q$ base) is a derivative of guanine that is involved in the biosynthetic pathway of the hypermodified tRNA nucleoside queuosine (Q) (Scheme 1) [5]. The core structure of the nucleobase is 7-aminomethyl-7-deazaguanine, a pyrrolo[2,3- 


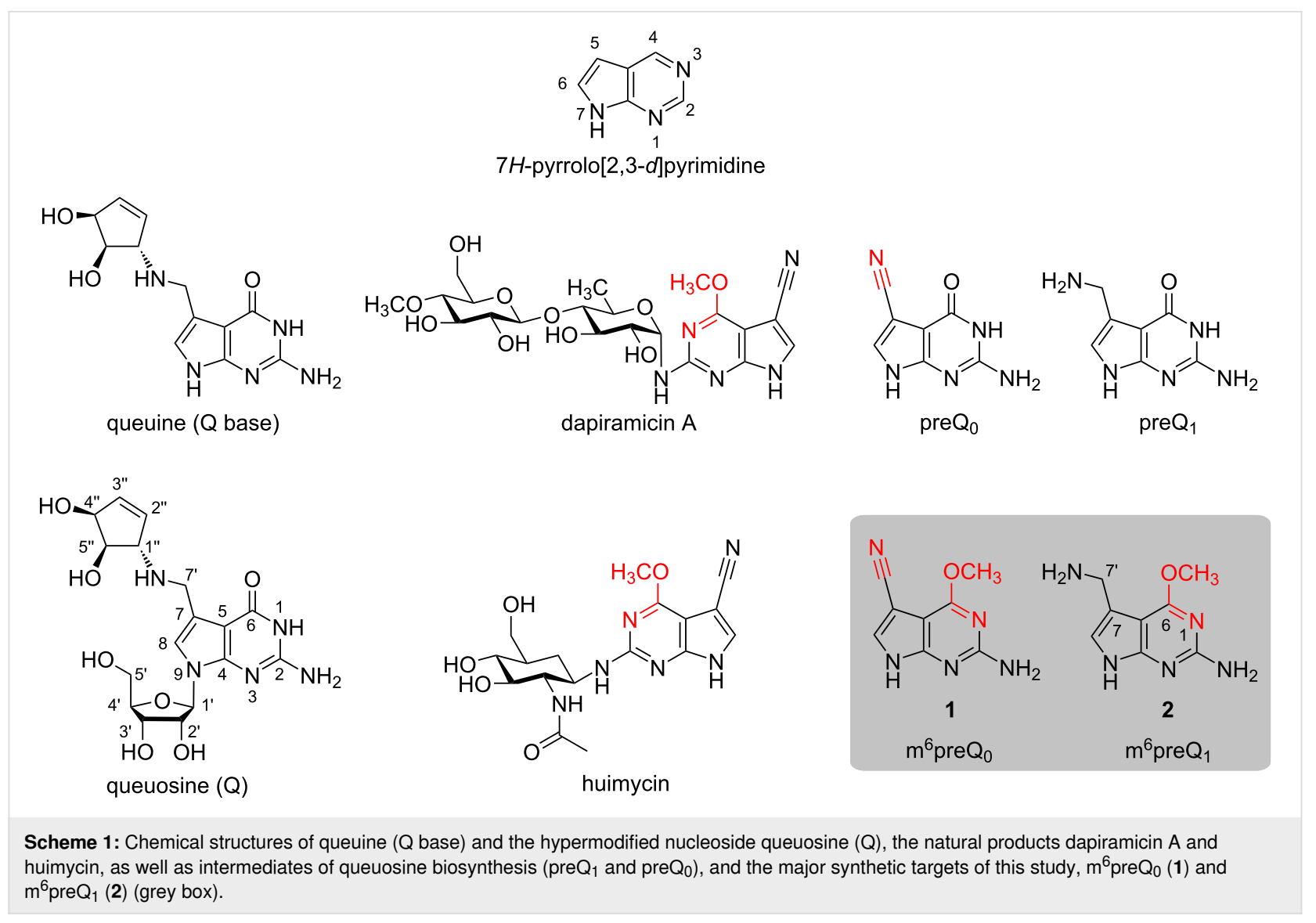

$d$ ]pyrimidine also termed prequeuosine base $\left(\mathrm{preQ}_{1}\right)[6,7]$. In many bacteria, pre $Q_{1}$ binds to specific mRNA domains and thereby regulates genes that are required for queuosine biosynthesis [8-16]. The molecular mechanism behind is called riboswitching. For most riboswitches, ligand binding induces a structural change in the untranslated leader sequence of mRNA by formation (or disruption) of a terminator stem (transcriptional control) or repressor stem (translational control). This conformational event signals on or off to gene expression and represents a feedback-type mechanism that is dependent on cellular ligand concentration [13].

\section{Natural occurrence of alkylated prequeuosines}

Evidence for the natural occurrence of methylated prequeuosine bases stems from a recent study that demonstrated that $\mathrm{m}^{6} \mathrm{preQ}_{0}$ is produced by Streptomyces [17]. Moreover, the natural products huimycin [18] and dapiramicin contain $\mathrm{m}^{6} \mathrm{preQ}_{0}$ as core with their $2-\mathrm{NH}_{2}$ group linked to a 2 -acetamido-2'-deoxy- 3 -D-glucopyranosyl residue in huimycin and to a 2-[4'-(4"-O-methyl- $\beta$-D-glucopyranosyl)-6'-deoxy- $\alpha$-Dglucopyranosyl] moiety in dapiramicin A $[19,20]$. In the biosynthetic pathway, the conversion of $\mathrm{pre}_{0}$ into huimycin requires methylation of preQ $_{0}$ and attachment of the $N$-acetylglucosamine moiety as final steps [18]. The methylation reaction is likely to be catalyzed by the product of the gene huiC, which encodes a SAM-dependent methyltransferase [18].

To the best of our knowledge, in contrast to $m^{6}$ preQ $_{0}$ [17] the reduced counterpart 7-aminomethyl- $O^{6}$-methyl-7-deazaguanine $\mathrm{m}^{6} \mathrm{preQ}_{1}$ has not yet been reported to be isolated from natural sources.

\section{Earlier syntheses of preQ $Q_{1}$, pre $Q_{0}$ and $m^{6}$ preQ $Q_{0}$}

The synthesis of $\mathrm{preQ}_{1}$ has been first described by Goto starting from 2-methylthio-6-methoxy-7-methyl-7-deazapurine and requiring more than ten steps [21]. More efficient was a procedure reported by Nishimura applying a Mannich reaction with dibenzylamine-formaldehyde and 2-acylaminopyrrolo[2,3d]pyrimidin-4(3H)-one as key step, thereby selectively installing a dibenzylaminomethyl moiety [22]. Exchange of the dibenzylamine group in the Mannich base with $\mathrm{NH}_{3}$ provided $\mathrm{preQ}_{1}$ [22]. Alternatively, Klebe demonstrated a Michael addition of 2,6-diaminopyrimidin-4-one to the nitroolefin 2-[(2E)-3nitroprop-2-en-1-yl]-1H-isoindole-1,3(2H)-dione [23]. Finally, Carell reported a cycloaddition route relying on $\alpha$-brominated 3-phthalimidopropanal and diaminopyrimidin-4-one [24,25]. We further optimized this path for the synthesis of ${ }^{15} \mathrm{~N}$-labeled prequeuosine nucleobase derivatives [26] required for ad- 
vanced NMR spectroscopic applications [27], and for the syntheses of azido- or amino-functionalized preQ $_{1}$ derivatives needed for cellular applications with engineered riboswitches [28]. Finally, we point out that only a single synthetic route has been published to a potential $O^{6}$-methylated precursor of $\mathrm{m}^{6} \mathrm{preQ}_{1}$, namely $N 9$-trimethysilylethyl protected $\mathrm{m}^{6} \mathrm{preQ}_{0}$ [20]. This synthesis, however, is based on methylation using diazomethane resulting in a mixture of $N 1$ and $O^{6}$ methylated products, and we therefore did not further consider this path. Finally, one route was described for $\mathrm{m}^{6} \mathrm{preQ}_{0} \mathbf{1}$ [29] which is similar to the first step we developed for the synthesis of $\mathrm{m}^{6} \mathrm{preQ}_{1} 2$ as outlined below.

\section{Synthesis of $m^{6}$ preq $_{1}, e^{6}$ preq $_{1}$, and bn ${ }^{6}$ preQ $_{1}$}

Our initial attempts to site-specifically methylate trimethylsilylated preQ $_{1}$ (which was generated in situ with $N, O$-bis[trimethylsilyl]acetamide) by trimethyloxonium tetrafluoroborate in apolar solvents resulted in the recovery of starting material only. Next, we tested a cyclocondensation reaction between 2-chloro-3-cyanopropan-1-al and 2,6-diamino-4-methoxypyrimidine [30], however, target compound $\mathbf{1}\left(\mathrm{m}^{6} \mathrm{preQ}_{0}\right)$ was obtained in yields of $21 \%$ (Scheme 2) which is significantly lower compared to the cyclocondensations with 2,6-diamino-4pyrimidin-4-one mentioned above [23-27].

We therefore envisaged a path involving 6-chloro-7-deazapurine derivative $\mathbf{3}$ (Scheme 3 ) as this compound is readily available from cheap starting materials following published procedures. Chloroacetonitrile and methyl formate gave 2-chloro2-cyanoacetaldehyde which was then reacted with 2,6diaminopyrimidin-4-one to provide $\mathrm{pre}_{0}$ in good yields [31]. Protection of the exocyclic amino group using pivaloyl chloride was optimized from a published procedure [32] and gave nearly quantitative yields of $N^{2}$-pivaloyl $\mathrm{preQ}_{0}$ in our hands. Finally, transformation of the 6-carbonyl group by using phosphorus oxychloride gave 6-chloro-7-deazapurine derivative 3 [33]. Notably, attempts to directly transform preQ $_{0}$ (without $N^{2}$ protection) into 6-chloro-7-cyano-7-deazaguanine failed in our hands.

The 6-chloro atom of compound $\mathbf{3}$ was substituted using sodium methoxide under concomitant cleavage of the pivaloyl group to yield the desired $O^{6}$-methylated compound $\mathbf{1}, \mathrm{m}^{6} \mathrm{preQ}_{0}$<smiles>Nc1cc(Cl)nc(N)n1</smiles>

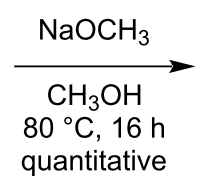

ref. [30]<smiles>COc1cc(N)nc(N)n1</smiles>

reflux, $17 \mathrm{~h}$

$21 \%$

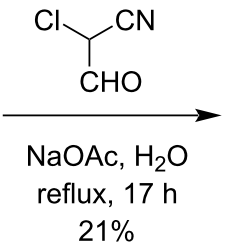

Scheme 2: Synthesis of compound $\mathbf{1}\left(\mathrm{m}^{6} \mathrm{preQ}_{0}\right)$ by cyclocondensation using a 4-methoxypyrimidine derivative resulted in unsatisfying yields.

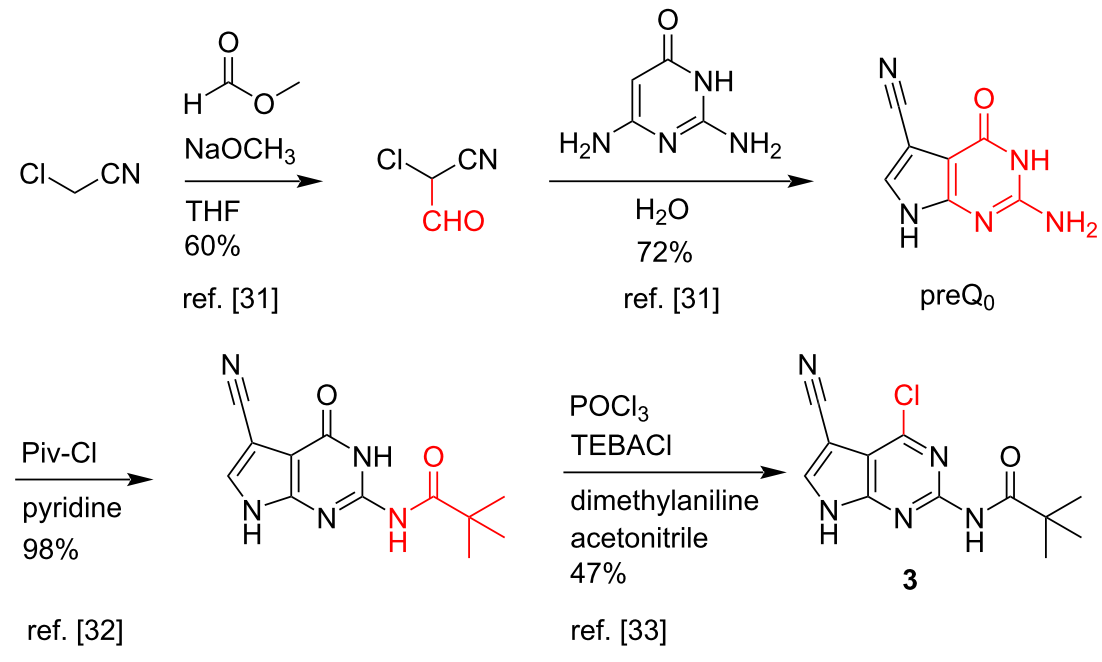


<smiles>CC(C)(C)C(=O)Nc1nc(Cl)c2c(C#N)c[nH]c2n1</smiles>

3<smiles>COc1nc(N)nc2[nH]cc(C#N)c12</smiles>

1<smiles>COc1ccc(C(Nc2nc(OC)c3c(C#N)cn(C(c4ccccc4)(c4ccccc4)c4ccc(OC)cc4)c3n2)(c2ccc(OC)cc2)c2ccc(OC)cc2)cc1</smiles>

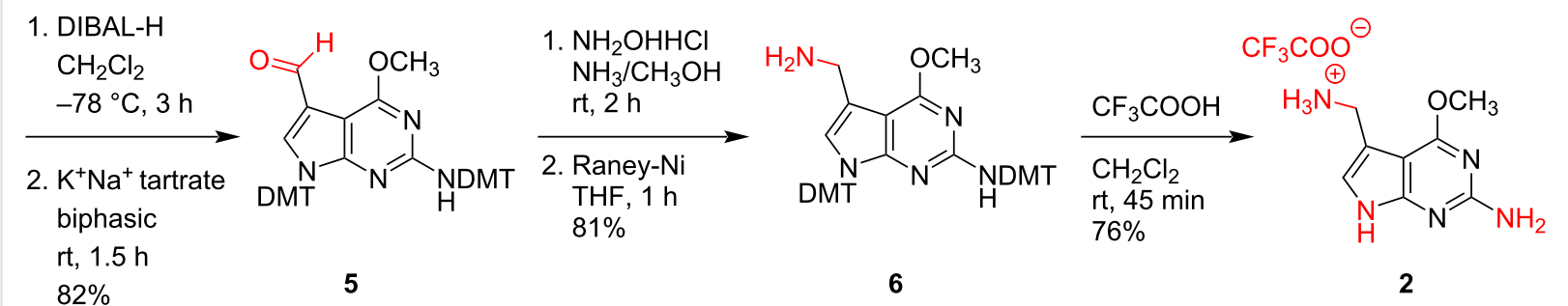

Scheme 4: The five-step synthesis of $\mathrm{m}^{6} \mathrm{preQ}_{1} 2$ from compound 3 required derivatization to make the intermediates soluble in organic solvents for a controllable reaction sequence to reduce the cyano group; overall yield: $30 \%$.

(Scheme 4). After dissolving this compound under strong silylating conditions in the presence of $\mathrm{N}, \mathrm{O}$-bis(trimethylsilyl)acetamide [34], simultaneous tritylation of $\mathrm{N} 9$ and the $\mathrm{N}^{2}$ atoms was achieved using 4,4'-dimethoxytrityl chloride in pyridine. The obtained derivative 4 was amenable to nitrile reduction using diisobutylaluminium hydride (DIBAL-H) in dichloromethane at $-78{ }^{\circ} \mathrm{C}$, followed by workup with potassium sodium tartrate solution (Rochelle salt) to furnish the aldehyde $\mathbf{5}$. Then, transformation of the 7-formyl into the 7-aminomethyl group proceeded via oxime formation, applying hydroxylamine hydrochloride in methanolic ammonia, followed by reduction with Raney nickel to yield the tritylated precursor $\mathbf{6}$. Finally, the auxiliary functions were cleaved using trifluoroacetic acid (TFA) in dichloromethane and the target compound $\mathbf{2}$, $\mathrm{m}^{6} \mathrm{preQ}_{1}$, was isolated as TFA salt.

The here established path to synthesize $\mathrm{m}^{6} \mathrm{preQ}_{1}$ offers high flexibility with respect to the $O^{6}$ substituent. We demonstrate this by complementing the set of $\mathrm{preQ}_{1}$-derived alkylating cofactors with $e^{6}$ preQ $_{1}(\mathbf{2 a})$ and $b^{6}{ }^{6} \mathrm{preQ}_{1}(\mathbf{2 b})$ that were synthesized following the same path with overall yields of $23 \%$ and $34 \%$, respectively (Scheme 5 and Supporting Information File 1).

\section{Conclusion}

We developed a robust synthesis for $O^{6}$-alkylated 7-aminomethyl-7-deazaguanines that starts from a readily accessible 6-chloro-7-cyano-7-deazaguanine derivative. The chloro atom

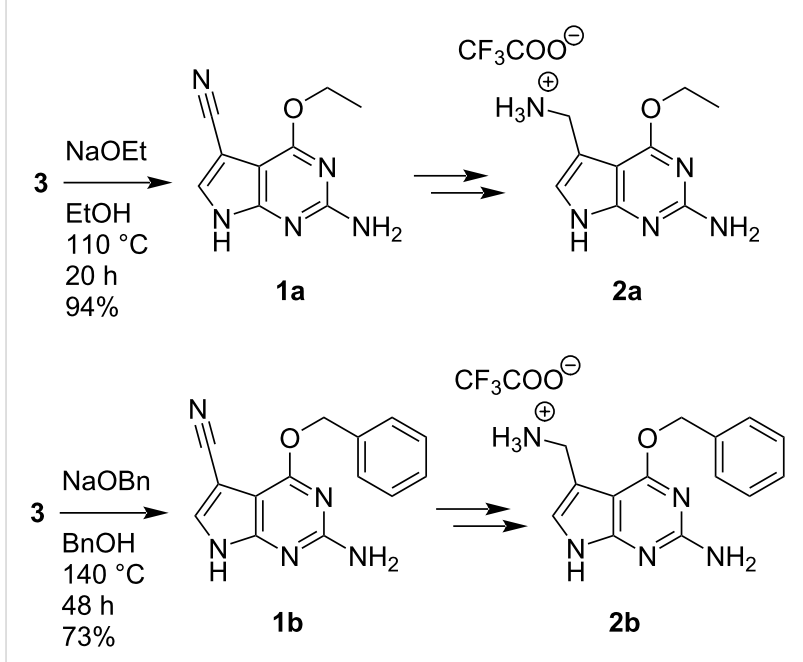

Scheme 5: The synthesis of $e^{6} \operatorname{preQ}_{1}(\mathbf{2 a})$ and $b n^{6}$ preQ $_{1}(\mathbf{2 b})$ was performed in analogy to the route outlined in Scheme 4 with an overall yield of $23 \%$ and $34 \%$, respectively. For details see the Supporting Information File 1.

is smoothly substituted by the alcoholate of interest, followed by N9 and $N^{2}$ dimethoxytritylation to obtain a well-soluble intermediate. The reduction of the 7-cyano substituent into the target aminomethyl group is accomplished by a hydration reaction sequence via in situ oxime formation. The route now provides a solid basis to generate $O^{6}$-alkylated preQ $\mathrm{Q}_{1}$ derivatives for the development of RNA labeling tools utilizing the RNA scaffold of the preQ $_{1}$ class-I riboswitch. 


\section{Experimental}

General. Chemical reagents and solvents were purchased from commercial suppliers (Sigma-Aldrich) and used without further purification. Organic solvents for reactions were dried overnight over freshly activated molecular sieves (4 ̊). The reactions were carried out under argon atmosphere. Analytical thin-layer chromatography (TLC) was performed on Marchery-Nagel Polygram SIL G/UV254 plates. Column chromatography was done on silica gel 60 (70-230 mesh). ${ }^{1} \mathrm{H}$, and ${ }^{13} \mathrm{C}$ NMR spectra were recorded on Bruker DRX $300 \mathrm{MHz}$, Bruker Avance $4 \mathrm{Neo}$ $400 \mathrm{MHz}$, and Bruker Avance $4 \mathrm{Neo} 700 \mathrm{MHz}$ instruments. Chemical shifts $(\delta)$ are reported relative to tetramethylsilane (TMS) and referenced to the residual proton or carbon signal of the deuterated solvent: $\mathrm{CDCl}_{3}(7.26 \mathrm{ppm})$ or DMSO- $d_{6}$ (2.49 ppm) for ${ }^{1} \mathrm{H} \mathrm{NMR} ; \mathrm{CDCl}_{3}(77.0 \mathrm{ppm})$ or DMSO- $d_{6}$ (39.5 ppm) for ${ }^{13} \mathrm{C}$ NMR spectra. ${ }^{1} \mathrm{H}$ and ${ }^{13} \mathrm{C}$ assignments are based on COSY, HSQC, and HMBC experiments. MS experiments were performed on a Thermo Fisher QExactive Classic. Samples were analyzed in the positive-ion mode.

$O^{6}$-Methyl preQ $\mathbf{Q}_{0}$ (1) $\left(\mathrm{m}^{6} \mathrm{preQ}_{0}\right)$. Procedure A: 2-Chloro-3oxoproanenitrile [29] (6.80 g, $65.6 \mathrm{mmol})$ was added to a solution of sodium acetate $(10.77 \mathrm{~g}, 131.3 \mathrm{mmol})$ and 6-methoxypyrimidine-2,4-diamine [33] $(9.20 \mathrm{~g}, 65.6 \mathrm{mmol})$ in water $(270 \mathrm{~mL})$ at $50{ }^{\circ} \mathrm{C}$. After 16 hours, the solution was refluxed for an additional hour and allowed to cool to room temperature. Filtration gave $2.61 \mathrm{~g}$ of compound $\mathbf{1}(21 \%)$ as grey solid. Procedure B: Sodium (42 mg, $1.8 \mathrm{mmol}$ ) was dissolved in $0.8 \mathrm{~mL}$ methanol at $0{ }^{\circ} \mathrm{C}$. Compound 3 [29-31] (200 mg, $0.720 \mathrm{mmol}$ ) was added and the mixture was heated to $110^{\circ} \mathrm{C}$ in a pressure tube for $24 \mathrm{~h}$. After neutralization with glacial acetic acid the volatiles were removed in vacuo. The crude product was dry-loaded onto silica gel and purified via flash column chromatography (5-20\% methanol in dichloromethane) to give $104 \mathrm{mg}$ of compound $\mathbf{1}(76 \%)$ as a beige solid. TLC: $10 \%$ methanol in dichloromethane, $R_{\mathrm{f}} 0.37 ;{ }^{1} \mathrm{H}$ NMR (300 MHz, DMSO-d $\left.{ }_{6}\right) \delta 12.08$ (bs, 1H, HN(9)), 7.81 (s, 1H, $\mathrm{HC}(8)), 6.45$ (s, 2H, $\left.\mathrm{H}_{2} \mathrm{~N}(2)\right), 3.96$ (s, 3H, $\left.\mathrm{H}_{3} \mathrm{CO}(6)\right) \mathrm{ppm}$; ${ }^{13} \mathrm{C}$ NMR (75 MHz, DMSO-d 6 ) $\delta 162.7$ (C(6)), 160.7 (C(2)), $154.9(\mathrm{C}(4)), 130.3(\mathrm{C}(8)), 116.1 \& 95.4 \& 82.4(\mathrm{C}(5) \& \mathrm{C}(7)$ \& $\mathrm{CN}), 53.26\left(\mathrm{H}_{3} \mathrm{CO}(6)\right)$; $\operatorname{ESIMS}(\mathrm{m} / \mathrm{z}):[\mathrm{M}+\mathrm{H}]^{+}$calcd, 190.0723; found, 190.0721 .

$N^{2}, 9-B i s\left(4,4^{\prime}\right.$-dimethoxytrityl)- $O^{6}$-methyl preQ $_{0}$ (4). Compound 1 (300 mg, $1.59 \mathrm{mmol}$ ) was suspended in $N, N$-dimethylformamide $(12 \mathrm{~mL}) . \mathrm{N}, O$-Bis(trimethylsilyl)acetamide $(820 \mu \mathrm{L}$, $3.33 \mathrm{mmol}$ ) was added dropwise and the reaction mixture was stirred for three hours at room temperature upon which a solution was obtained. Afterwards, the volatile components were removed under reduced pressure and the residue was coevaporated three times with toluene and twice with pyridine. The residue was dissolved in pyridine $(3.8 \mathrm{~mL})$ and 4,4'-dimethoxytrityl chloride ( $1.18 \mathrm{~g}, 3.50 \mathrm{mmol}$ ) was added in portions. The solution was stirred for $18 \mathrm{~h}$ at $40{ }^{\circ} \mathrm{C}$, subsequently poured into $5 \%$ aqueous sodium bicarbonate solution and the suspension was extracted three times with dichloromethane. The combined organic layers were washed with brine and dried over magnesium sulfate. The solvents were removed and the remaining crude product was purified by flash column chromatography on silica gel (10-30\% ethyl acetate in cyclohexane) to give $1.00 \mathrm{~g}$ of compound 4 (79\%) as a white foam. TLC: $40 \%$ ethyl acetate in cyclohexane, $R_{\mathrm{f}}=0.68 ;{ }^{1} \mathrm{H}$ NMR $\left(300 \mathrm{MHz} \mathrm{CDCl}_{3}\right) \delta$ 7.32-6.94 (m, 19H, HC(aromatic, DMTr) \& HC(8)), 6.83-6.65 (m, 8H, HC(arom, DMTr)), 5.54 (s, 1H, HN(2)), 3.80 \& 3.77 (s, $12 \mathrm{H}, \mathrm{H}_{3} \mathrm{CO}$ (DMTr), 3.37 (s, $1 \mathrm{H}, \mathrm{H}_{3} \mathrm{CO}(\mathrm{O} 6) \mathrm{ppm} ;{ }^{13} \mathrm{C} \mathrm{NMR}$ $\left(101 \mathrm{MHz}, \mathrm{CDCl}_{3}\right) \delta 162.4(\mathrm{C}(6)), 158.7 \& 158.4 \& 158.0$ (C(aromatic, DMTr)), 154.8 (C(4)), $146.3(\mathrm{C}(2)), 142.15 \&$ $138.4 \& 134.3$ (C(aromatic, DMTr)), 133.1 (C(8)), $131.4 \&$ $130.4 \& 130.3 \& 130.2 \& 129.80 \& 129.1 \& 127.8 \& 127.5 \&$ $127.4 \& 126.4$ (C(aromatic, DMTr)), 115.8 (C(5)/C(7)), 113.3 \& $113.1 \& 112.7$ (C(aromatic, DMTr)), $99.2(\mathrm{C}(5) / \mathrm{C}(7)), 83.1$ $(\mathrm{CN}($ nitrile $)), 76.1 \& 70.5\left(\mathrm{CAr}_{3}(\mathrm{DMTr})\right), 55.4 \& 55.3$ $\left(\mathrm{H}_{3} \mathrm{CO}(\mathrm{DMTr})\right), 53.88\left(\mathrm{H}_{3} \mathrm{CO}(6)\right) \mathrm{ppm}$; ESIMS $(\mathrm{m} / \mathrm{z})$ : $[\mathrm{M}+\mathrm{H}]^{+}$calcd, 794.3337; found, 794.3321.

\section{7-Formyl- $N^{2}$,9-bis(4,4'-dimethoxytrityl)- $O^{6}$-methyl-7-deaza-} guanine (5). To a cooled solution $\left(-78{ }^{\circ} \mathrm{C}\right)$ of compound 4 $(1.00 \mathrm{~g}, 1.26 \mathrm{mmol})$ in dichloromethane $(8 \mathrm{~mL})$ diisobutylaluminium hydride (1 $\mathrm{M}$ in dichloromethane, $1.6 \mathrm{~mL}, 2.57 \mathrm{mmol}$ ) was added dropwise. The reaction was continued for three hours, quenched by the addition of ethyl acetate $(4 \mathrm{~mL})$ and allowed to come to room temperature. Half-saturated potassium sodium tartrate solution was added $(4 \mathrm{~mL})$ and the biphasic mixture was stirred vigorously for one and a half hour until satisfactory phase separation was achieved. The aqueous layer was separated and subsequently extracted three times with ethyl acetate. The combined organic layers were washed with brine, dried over magnesium sulfate and evaporated. The residue was purified by flash column chromatography on silica gel (10-25\% ethyl acetate in cyclohexane) to give $823 \mathrm{mg}$ of compound 5 (82\%) as a white foam. TLC: $30 \%$ ethyl acetate in cyclohexane $R_{\mathrm{f}} 0.51 ;{ }^{1} \mathrm{H} \mathrm{NMR}\left(\mathrm{CDCl}_{3}, 400 \mathrm{MHz}\right) \delta 9.91$ (s, $1 \mathrm{H}, \mathrm{CHO}$ ), 7.49 (s, 1H, HC(8)), 7.29-7.23 (m, 2H, HC(aromatic, DMTr), 7.20-7.11 (m, 6H, HC(aromatic, DMTr), 7.10-7.06 (m, 2H, HC(aromatic, DMTr)), 7.05-6.92 (m, 8H, HC(aromatic, DMTr)), 6.81-6.76 (m, 4H, HC(aromatic, DMTr)), 6.72-6.68 (m, 4H, HC(aromatic, DMTr)), 5.51 (s, 1H, HN(2)), 3.80 (s, 6H, $\mathrm{H}_{3} \mathrm{CO}(\mathrm{DMTr})$ ), 3.77 (s, 6H, $\mathrm{H}_{3} \mathrm{CO}(\mathrm{DMTr})$ ), 3.38 (s, $\left.3 \mathrm{H}, \mathrm{H}_{3} \mathrm{CO}(6)\right) \mathrm{ppm} ;{ }^{13} \mathrm{C} \mathrm{NMR}\left(\mathrm{CDCl}_{3}, 101 \mathrm{MHz}\right) \delta 185.7$ (CHO), $163.2(\mathrm{C}(6)), 158.7 \& 158.0 \& 156.5$ (C(aromatic, DMTr)), 156.5 (C(4)), 146.4 (C(2)), $142.3 \& 138.6 \& 134.5$ (C(aromatic, DMTr)), 131.9 (C(8)), $131.5 \& 130.3 \& 129.9 \&$ 
$129.1 \& 127.7 \& 127.4 \& 127.3 \& 126.4$ (C(aromatic, DMTr)), $115.7(\mathrm{C}(5) / \mathrm{C}(7)), 113.1 \& 112.7$ (C(aromatic, DMTr)), 98.0 $(\mathrm{C}(5)) / \mathrm{C}(7)), 76.0$ (CAr 3 (DMTr)), 70.5 (DMTr), $55.4 \& 33.3$ $\left(\mathrm{H}_{3} \mathrm{CO}(\mathrm{DMTr})\right), 54.0\left(\mathrm{H}_{3} \mathrm{CO}(6)\right)$ ppm; ESIMS $(\mathrm{m} / \mathrm{z}):[\mathrm{M}+\mathrm{H}]^{+}$ calcd, 797.3334; found, 797.3315.

7-Aminomethyl- $N^{2}$,9-bis(4,4'-dimethoxytrityl)- $O^{\mathbf{6}}$-methyl-7deazaguanine (6). To a suspension of compound 5 (200 mg, $0.251 \mathrm{mmol})$ in $7 \mathrm{M}$ methanolic ammonia $(6 \mathrm{~mL})$ hydroxylamine hydrochloride ( $21 \mathrm{mg}, 0.300 \mathrm{mmol}$ ) was added. A clear solution was obtained shortly thereafter. The reaction was stirred for two hours at room temperature. Tetrahydrofuran (4 mL) and damp Raney-Nickel (approximately $200 \mathrm{mg}$ ) were introduced and the reaction was continued for one hour. The reaction mixture was filtered over a Celite pad and the filtrate was evaporated. The residue was taken up in $3 \%$ methanol in dichloromethane and passed over a short, deactivated silica pad and evaporated once more to give $163 \mathrm{mg}$ of compound 6 $(81 \%)$ as a white foam. TLC: $6 \% \mathrm{MeOH}, 1 \% \mathrm{NEt}_{3}$ in dichloromethane, $R_{\mathrm{f}} 0.26 ;{ }^{1} \mathrm{H} \mathrm{NMR}\left(\mathrm{CDCl}_{3}, 400 \mathrm{MHz}\right) \delta 7.24-7.20(\mathrm{~m}$, $3 \mathrm{H}, \mathrm{HC}($ aromatic, DMTr) ), 7.18-7.08 (m, 7H, HC(aromatic, DMTr)), 7.06-7.00 (m, 8H, HC(aromatic, DMTr)), 6.77-6.67 (m, 7H, HC(aromatic, DMTr)), 6.44 (s, 1H, HC(8)), 5.46 (s, $1 \mathrm{H}, \mathrm{HN}(2)), 3.79$ (s, 6H, $\left.\mathrm{H}_{3} \mathrm{CO}(\mathrm{DMTr})\right), 3.77$ (s, 6H, $\mathrm{H}_{3} \mathrm{CO}(\mathrm{DMTr})$ ), 3.67 (s, 2H, $\mathrm{H}_{2} \mathrm{CC}(7)$ ), 3.33 (s, 3H, $\mathrm{H}_{3} \mathrm{CO}(6)$ ), 1.81 (bs, $\left.2 \mathrm{H}, \mathrm{H}_{2} \mathrm{~N}\right) \mathrm{ppm} ;{ }^{13} \mathrm{C} \mathrm{NMR}\left(\mathrm{CDCl}_{3}, 101 \mathrm{MHz}\right) \delta 162.3$ (C(6)), $158.3 \& 157.8 \& 157.2 \&$ (C(arom, DMTr)), 155.9 $(\mathrm{C}(4)), 146.8(\mathrm{C}(2)), 143.6 \& 139.0 \& 135.9 \& 131.4130 .4 \&$ $130.0 \& 129.2 \& 127.4 \& 127.3 \& 126.8 \& 126.2$ (C(arom, DMTr)), $121.4(\mathrm{C}(8)), 115.9(\mathrm{C}(5))$ or $(\mathrm{C}(7)), 112.71 \& 112.6$ (C(arom, DMTr)), 74.5 (CAr 3 (DMTr)), $70.3\left(\mathrm{CAr}_{3}(\mathrm{DMTr})\right)$, $55.3\left(\mathrm{H}_{3} \mathrm{CO}(\mathrm{DMTr})\right), 53.4\left(\mathrm{H}_{3} \mathrm{CO}(6)\right), 38.9\left(\mathrm{H}_{2} \mathrm{CC}(7)\right) \mathrm{ppm}$; ESIMS $(\mathrm{m} / \mathrm{z}):[\mathrm{M}+\mathrm{H}]^{+}$calcd, 798.3650; found, 798.3629.

$O^{6}$-Methyl preQ $Q_{1}$ (trifluoroacetate salt) (2). Compound 6 (120 mg, $150 \mu \mathrm{mol})$ was dissolved in $500 \mu \mathrm{L}$ dichloromethane. Trifluoroacetic acid $(60 \mu \mathrm{L}, 0.75 \mathrm{mmol})$ and $10 \mu \mathrm{L}$ water were added. After 45 minutes the reaction was quenched by the addition of $100 \mu \mathrm{L}$ methanol. Afterwards the solvents were removed in vacuo. The residue was triturated five times with dichloromethane and dried on high vacuum to give $35 \mathrm{mg}$ of compound $2(76 \%)$ as a white solid. TLC: $15 \% \mathrm{MeOH}, 1 \%$ $\mathrm{NEt}_{3}$ in dichloromethane, $R_{\mathrm{f}} 0.56 ;{ }^{1} \mathrm{H} \mathrm{NMR}\left(\mathrm{CDCl}_{3}, 400 \mathrm{MHz}\right)$ $\delta 11.64$ (bs, $1 \mathrm{H}, \mathrm{HN}(9), 8.07$ (bs, $\left.3 \mathrm{H}, \mathrm{H}_{3} \mathrm{~N}^{+}\right), 6.99$ (d, $1 \mathrm{H}, J_{\mathrm{HH}}$ $=2.0 \mathrm{~Hz}, \mathrm{HC}(8)), 4.06\left(\mathrm{q}, 2 \mathrm{H}, \mathrm{H}_{2} \mathrm{CC}(7)\right), 3.98\left(\mathrm{~s}, 3 \mathrm{H}, \mathrm{H}_{3} \mathrm{CO}\right)$ ppm; ${ }^{13} \mathrm{C} \mathrm{NMR}\left(\mathrm{CDCl}_{3}, 101 \mathrm{MHz}\right) \delta 164.1(\mathrm{C}(6)), 158.4$ (q, $\left.J_{\mathrm{CF}}=34.0 \mathrm{~Hz}, \mathrm{CF}_{3} \mathrm{COO}^{-}\right), 158.1(\mathrm{C}(2)), 150.7(\mathrm{C}(4)), 120.0$ $(\mathrm{C}(8)), 116.3\left(\mathrm{q}, J_{\mathrm{CF}}=295.0 \mathrm{~Hz}, \mathrm{CF}_{3} \mathrm{COO}^{-}\right), 107.5 \& 96.2$ $\left((\mathrm{C}(5) \& \mathrm{C}(7)), 53.7\left(\mathrm{H}_{3} \mathrm{CO}\right), 34.8\left(\mathrm{CH}_{2} \mathrm{CC}(7)\right)\right.$ ppm; ESIMS $(\mathrm{m} / \mathrm{z}):\left[\mathrm{M}+\mathrm{H}-\mathrm{NH}_{3}\right]^{+}$calcd, 177.0771; found, 177.0767; $[\mathrm{M}+\mathrm{H}]^{+}$calcd, 194.1036; found, 194.1032.

\section{Supporting Information}

\section{Supporting Information File 1}

Synthetic procedures for compounds $1 \mathbf{a}-\mathbf{6 a}$, and $\mathbf{1 b}-\mathbf{6} \mathbf{b}$, and ${ }^{1} \mathrm{H}$ and ${ }^{13} \mathrm{C}$ NMR spectra of all compounds. ${ }^{1} \mathrm{H},{ }^{13} \mathrm{C}$ HSQC and ${ }^{1} \mathrm{H},{ }^{13} \mathrm{C}$ HMBC spectra of all final products $\mathbf{1}$,

1a, 1b, 2, 2a, and $\mathbf{2 b}$.

[https://www.beilstein-journals.org/bjoc/content/ supplementary/1860-5397-17-147-S1.pdf]

\section{Acknowledgements}

We thank Maximilian Himmelstoß (Innsbruck) for mass spectrometric measurements, Christoph Kreutz (Innsbruck) for NMR spectroscopic support, and Daniel Fellner (Innsbruck) for technical support.

\section{Funding}

We thank the following institutions for funding: Austrian Science Fund FWF [P31691, F8011-B to R.M.]; Austrian Research Promotion Agency FFG [West Austrian BioNMR 858017].

\section{ORCID ${ }^{\circledR}$ iDs}

Ronald Micura - https://orcid.org/0000-0003-2661-6105

\section{References}

1. Flemmich, L.; Heel, S.; Moreno, S.; Breuker, K.; Micura, R. Nat. Commun. 2021, 12, 3877. doi:10.1038/s41467-021-24193-7

2. Breaker, R. R. ACS Chem. Biol. 2020, 15, 2020-2030. doi:10.1021/acschembio.0c00214

3. Batey, R. T. RNA 2015, 21, 560-563. doi:10.1261/rna.050765.115

4. Micura, R.; Höbartner, C. Chem. Soc. Rev. 2020, 49, 7331-7353. doi:10.1039/d0cs00617c

5. McCarty, R. M.; Bandarian, V. Bioorg. Chem. 2012, 43, 15-25. doi:10.1016/j.bioorg.2012.01.001

6. Iwata-Reuyl, D. Bioorg. Chem. 2003, 31, 24-43. doi:10.1016/s0045-2068(02)00513-8

7. Vinayak, M.; Pathak, C. Biosci. Rep. 2010, 30, 135-148. doi:10.1042/bsr20090057

8. Roth, A.; Winkler, W. C.; Regulski, E. E.; Lee, B. W. K.; Lim, J.; Jona, I.; Barrick, J. E.; Ritwik, A.; Kim, J. N.; Welz, R.; Iwata-Reuyl, D.; Breaker, R. R. Nat. Struct. Mol. Biol. 2007, 14, 308-317. doi:10.1038/nsmb1224

9. Meyer, M. M.; Roth, A.; Chervin, S. M.; Garcia, G. A.; Breaker, R. R. RNA 2008, 14, 685-695. doi:10.1261/rna.937308

10. McCown, P. J.; Liang, J. J.; Weinberg, Z.; Breaker, R. R. Chem. Biol. 2014, 21, 880-889. doi:10.1016/j.chembiol.2014.05.015

11. Jenkins, J. L.; Krucinska, J.; McCarty, R. M.; Bandarian, V.; Wedekind, J. E. J. Biol. Chem. 2011, 286, 24626-24637. doi:10.1074/jbc.m111.230375

12. Chatterjee, S.; Chauvier, A.; Dandpat, S. S.; Artsimovitch, I.; Walter, N. G. Proc. Natl. Acad. Sci. U. S. A. 2021, 118, e2023426118. doi:10.1073/pnas.2023426118 
13. Serganov, A.; Nudler, E. Cell 2013, 152, 17-24. doi:10.1016/j.cell.2012.12.024

14. Zallot, R.; Yuan, Y.; de Crécy-Lagard, V. Biomolecules 2017, 7, 12. doi:10.3390/biom7010012

15. Iwata-Reuyl, D. Curr. Opin. Chem. Biol. 2008, 12, 126-133. doi:10.1016/j.cbpa.2008.01.041

16. Gaur, R.; Varshney, U. J. Bacteriol. 2005, 187, 6893-6901. doi:10.1128/jb.187.20.6893-6901.2005

17. lijima, M.; Kubota, Y.; Sawa, R.; Kubota, Y.; Hatano, M.; Igarashi, M.; Kawada, M.; Momose, I.; Takekawa, M.; Shibasaki, M. J. Antibiot. 2018, 71, 135-138. doi:10.1038/ja.2017.100

18. Shuai, H.; Myronovskyi, M.; Nadmid, S.; Luzhetskyy, A. Biomolecules 2020, 10, 1074. doi:10.3390/biom10071074

19. Nishizawa, N.; Kondo, Y.; Koyama, M.; Omoto, S.; Iwata, M.; Tsuruoka, T.; Inouye, S. J. Antibiot. 1984, 37, 1-5. doi:10.7164/antibiotics.37.1

20. Ohno, H.; Terui, T.; Kitawaki, T.; Chida, N. Tetrahedron Lett. 2006, 47, 5747-5750. doi:10.1016/j.tetlet.2006.06.001

21. Ohgi, T.; Kondo, T.; Goto, T. Chem. Lett. 1979, 8, 1283-1286. doi:10.1246/cl.1979.1283

22. Akimoto, H.; Imamiya, E.; Hitaka, T.; Nomura, H.; Nishimura, S. J. Chem. Soc., Perkin Trans. 1 1988, 1637-1644. doi:10.1039/p19880001637

23. Gerber, H.-D.; Klebe, G. Org. Biomol. Chem. 2012, 10, 8660-8668. doi:10.1039/c2ob26387d

24. Klepper, F.; Polborn, K.; Carell, T. Helv. Chim. Acta 2005, 88, 2610-2616. doi:10.1002/hlca.200590201

25. Barnett, C. J.; Grubb, L. M. Tetrahedron 2000, 56, 9221-9225. doi:10.1016/s0040-4020(00)00895-4

26. Levic, J.; Micura, R. Beilstein J. Org. Chem. 2014, 10, 1914-1918. doi:10.3762/bjoc. 10.199

27. Moschen, T.; Wunderlich, C. H.; Spitzer, R.; Levic, J.; Micura, R.; Tollinger, M.; Kreutz, C. Angew. Chem., Int. Ed. 2015, 54, 560-563. doi:10.1002/anie.201409779

28. Neuner, E.; Frener, M.; Lusser, A.; Micura, R. RNA Biol. 2018, 15 , 1376-1383. doi:10.1080/15476286.2018.1534526

29. Khalaf, A. I.; Huggan, J. K.; Suckling, C. J.; Gibson, C. L.; Stewart, K.; Giordani, F.; Barrett, M. P.; Wong, P. E.; Barrack, K. L.; Hunter, W. N. J. Med. Chem. 2014, 57, 6479-6494. doi:10.1021/jm500483b

30. Chang, L.; Lee, S.-Y.; Leonczak, P.; Rozenski, J.; De Jonghe, S.; Hanck, T.; Müller, C. E.; Herdewijn, P. J. Med. Chem. 2014, 57, 10080-10100. doi:10.1021/jm501434y

31. Zhu, G.; Liu, Z.; Xu, Y.; Mao, Z. Heterocycles 2008, 75, 1631-1638. doi:10.3987/com-08-11323

32. Wilding, B.; Winkler, M.; Petschacher, B.; Kratzer, R.; Egger, S.; Steinkellner, G.; Lyskowski, A.; Nidetzky, B.; Gruber, K.; Klempier, N. Chem. - Eur. J. 2013, 19, 7007-7012. doi:10.1002/chem.201300163

33. Brückl, T.; Klepper, F.; Gutsmiedl, K.; Carell, T. Org. Biomol. Chem. 2007, 5, 3821-3825. doi:10.1039/b713309j

34. Brooks, A. F.; Garcia, G. A.; Showalter, H. D. H. Tetrahedron Lett. 2010, 51, 4163-4165. doi:10.1016/j.tetlet.2010.06.008

\section{License and Terms}

This is an Open Access article under the terms of the Creative Commons Attribution License (https://creativecommons.org/licenses/by/4.0). Please note that the reuse, redistribution and reproduction in particular requires that the author(s) and source are credited and that individual graphics may be subject to special legal provisions.

The license is subject to the Beilstein Journal of Organic Chemistry terms and conditions: (https://www.beilstein-journals.org/bjoc/terms)

The definitive version of this article is the electronic one which can be found at: https://doi.org/10.3762/bjoc.17.147 